\title{
Off-Label Use
}

National Cancer Institute

\section{Source}

National Cancer Institute. Off-Label Use. NCI Thesaurus. Code C63082.

Problem associated with the device which has been used for an unapproved indication or for an unapproved intended use. 